University of California

Division of Agriculture and Natural Resources

http://anrcatalog.ucdavis.edu

\title{
Agritourism enterprises on your farm or ranch: Where to start
}

HOLLY GEORGE, UC Cooperative Extension Livestock and Natural Resource Advisor, Plumas and Sierra Counties; and ELLIE RILLA, UC Cooperative Extension Community Development Advisor, Marin County

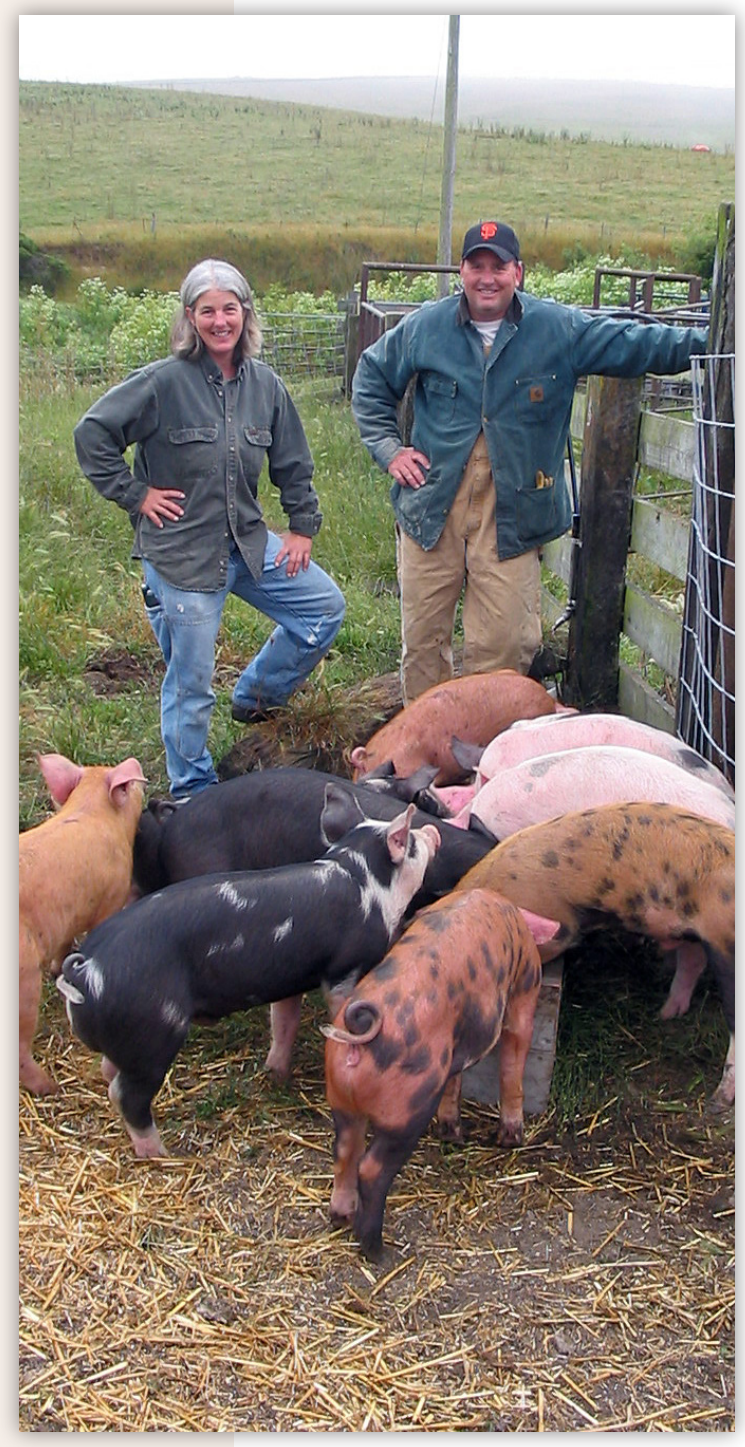

Agritourism in California has the potential to profitably direct market farm products and services, to serve as an alternative use of farm and ranch land, or to supplement your farm income. But numerous regulations-many complex-face landowners interested in establishing an agritourism enterprise. Regulations are part of doing business, and your compliance with them helps protect operators as well as consumers from potential liabilities.

You can best address the regulatory bureaucracy one step at a time. ANR Publication 8333 helps you understand regulations, and this publication explains where to start with these regulations in relation to your agritourism enterprise. You can also learn more about other aspects of the agritourism business 3484 Agritourism and Nature Tourism in California (George and Rilla, 2005).

"Agritourism" includes any income-generating activity conducted on a working farm or ranch for the enjoyment and education of visitors. This includes the interpretation of the natural, cultural, historical, and environmental assets of the land and the people working on it.

Agritourism helps you build supportive relationships with the consuming public both in rural communities and in agricultural areas on the urban fringe. Increased public interaction with area farms and ranches builds an understanding and appreciation for working landscapes that can help maintain or enhance natural resource values too. 


\section{Regulations and Your Business: Where to Start}

When you take this regulatory journey one step at a time, you'll find it much easier. Research the process, and then ask a lot of questions. The more you know

Address the regulatory bureaucracy one step at a time and develop a good working relationship with all agency staff.
Remember-early in the process talk with neighbors, share your plans, address any concerns they may have, and garner their support before going to planning. in advance, the better questions you'll ask and the more prepared you'll be to prevent costly delays and difficulties.

\section{Do Your Homework}

First make sure that your county allows your kind of enterprise to operate in the designated land use zone. Start with a visit to your county planning department. Bring your assessor's parcel number, which can be found on your tax bill. It will help you identify which zone covers your property.

Request information about land use and conditions. You'll need

- the zoning map. (Establish the exact zone in which your property lies. If you need resource inventory maps to help you identify special features that could impact your plans, ask the county planning department staff members. They usually can direct you to these maps.)

- the text listing all allowable uses in your zone and all conditions that affect those uses. (Watch for references to other codes or sections, and obtain copies of those materials too.)

- local, state, and federal requirements and guidelines specific to your activity.

- explanations of any regulation or condition you don't understand.

- You still need an application form for permittedby-right activities, though it will probably be quite simple.

- If, however, you find your operation requires a use permit, then you must learn all you can about the use permit application and approval process.

- Ask for an application for your proposed use and a fee schedule.

- Ask about documentation that must be filed with the application-maps, sketches, letters from fire district, water district, and so forth.

- Ask about filing deadlines and application approval procedures.
- Ask whether anyone else in the county is doing the same thing as you-and when and how they received permission.

- Ask who makes the decision. Counties differ.

- Ask whether any decisions are made "over the counter."

- Ask whether any hearings are needed. Who holds the hearings? Who gets notices of the hearings and the application?

\section{Prepare a Project Description}

Before you sit down with county staff to discuss your project in detail, prepare a brief project description, and obtain a plot map for your property. Gather additional information, including

- the anticipated number of visitors and months operational

- the existing and proposed water and sewage/septic systems

- the surrounding land uses

- road access to the property

- timing or schedule issues

- status of Williamson Act contracts.

\section{Meet with Agency Staff}

It is critical you meet with representatives of every agency or department that might impact your enterprise. You can either call on each agency individually or visit with representatives of all relevant agencies in a "roundtable" or "predevelopment" meeting. Whatever your method, make sure that you and your county share the same understanding about codes and requirements. Listen carefully to objections and concerns. It is easier and cheaper to change your agritourism plans when you begin the process than it is to fight through appeals after you've spent time and money.

\section{Submit a Complete Application}

After you have researched the regulations likely to affect your enterprise, meet with key players and collect the required applications. You are ready to assemble and submit your use permit application package. You submit this package to the county planning department. A completed application package usually contains

1. a written description of the type and nature of the existing and proposed uses 


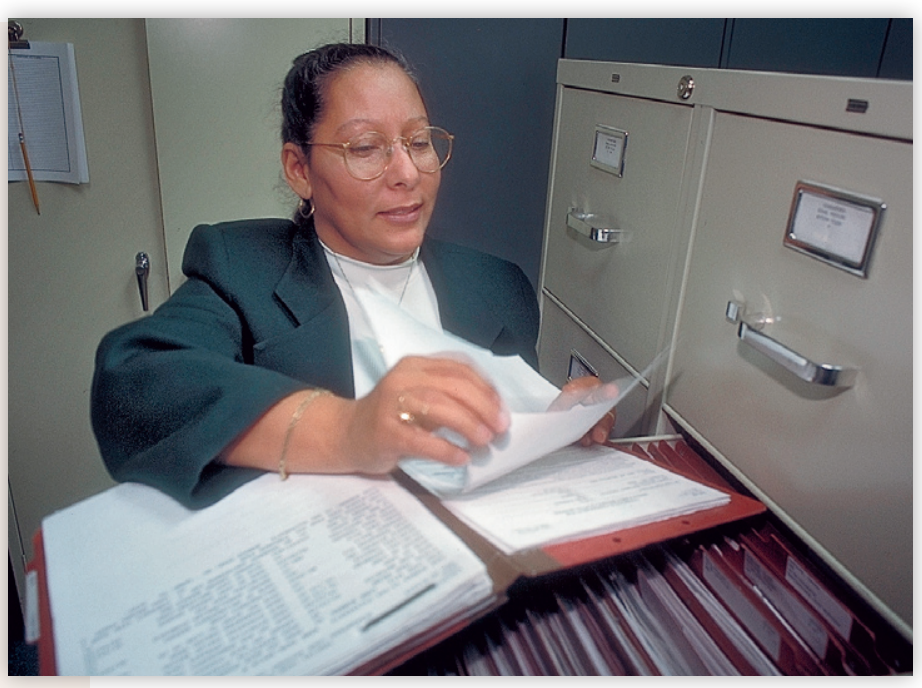

\section{Tip}

Develop positive relationships with the staff of your county planning and environmental health departments. Find out who you work best with and return to that person. In large counties, you'll likely get whomever works the planning counter that day. Clearly explain your plans to them so they understand your intentions. Bear in mind the following:

- Make allies, not adversaries, of your local county officials.

- Ask questions and seek their advice.

- Take time to educate. Remember that few people actually understand how agriculture works.

- Know that regulations are not set in stone; there often is leeway in their interpretation. There also might be out-of-date and unnecessary regulations
2. multiple copies of the following items drawn to scale:

- site plan showing

a. name, address, and phone number of the owner of record, applicant, engineer, architect

b. a north arrow

c. the date; revised copies should be clearly identified

d. the property dimensions

e. all dimensions of existing and proposed buildings and of additions

f. the distance of proposed structures and additions to adjacent property lines

g. parking locations

h. the existing and proposed topography

i. the inundated areas, streams, culverts, drainage, swales

- building elevations

- floor plans

- location map showing your subject property to the nearest street

\section{Putting the Pieces Together: The Use Permit Approval Process}

Although each county has its own requirements and procedures, there are steps in the permit process common to most counties. Because each county has its own specific permit requirements and fees, it would be difficult if not impossible to list the differences in this publication.
Step One: Exploring the Permitting Process

After you've determined that the county allows your planned activity and that you need a use permit, then your next step is to explore the permitting process ahead of you. Meet informally with the county planning department to discuss your plans.

Step Two: Submitting the Application and Forms After meeting with planning department and other agencies, use what you learned to complete the required forms. You must submit your use permit application and other pertinent documents to the planning department, along with an application fee.

Step Three: Making Sure It's Complete

The planner assigned to your project makes sure your application is complete. California state law requires that the planner complete this step within 30 days of the proposal's submission. The planner will send you an "application notice" revealing your status: whether your application is complete and-if it is incomplete-what items must be submitted before processing can begin.

\section{Step Four: Processing the Application}

The planner assigned to process your application sends it along with your plans and other material to county departments and agencies. They review, comment, and provide recommendations. If additional information is needed to fully assess your proposal's impact and conditions, the planner will request it of you.

\section{Step Five: Notifying the Public}

Once it is determined your application is complete, the county planning department will send a notice to landowners near your farm or ranch. This notice will state the date, time, and place of a public hearing.

\section{Step Six: Determining the Action}

At the public hearing, your application can be approved, approved with conditions, or denied. The zoning administrator will consider public testimony and any information or comments from relevant departments, agencies, and design review boards.

\section{Step Seven: Appealing the Action}

The action of the zoning administrator is final unless appealed. If you appeal the action, you must file your appeal with the planning department within 10 calendar days from the date of the action. Check with your county's zoning counter personnel to learn about fees and the appeal process. 


\section{Figure 1}

\begin{tabular}{|c|c|c|c|c|}
\hline \multicolumn{5}{|c|}{ Regulatory Agency Worksheet } \\
\hline Jurisdiction & Agency & Permit or Fee & Start-up Cost & Annual Cost \\
\hline \multirow[t]{15}{*}{ County } & \multirow[t]{3}{*}{ Agricultural Commissioner } & Scale certification & & \\
\hline & & Organic inspection & & \\
\hline & & Labeling inspection & & \\
\hline & \multirow[t]{2}{*}{ Treasurer / Tax Collector } & Business tax and license & & \\
\hline & & Transient occupancy tax registration & & \\
\hline & Building Department & Building permit & & \\
\hline & Planning Department & Use permit & & \\
\hline & \multirow{4}{*}{$\begin{array}{l}\text { Environmental Health } \\
\text { Department }\end{array}$} & Food safety permit & & \\
\hline & & Food processing permit & & \\
\hline & & Increased or new septic permit & & \\
\hline & & Increased or new well permit & & \\
\hline & \multirow[t]{2}{*}{ Public Works } & Entry onto county roads permit & & \\
\hline & & Signs permit & & \\
\hline & Recorder & Fictitious name filing & & \\
\hline & Fire Agency & Safety and occupancy inspections & & \\
\hline \multirow[t]{7}{*}{ State } & California Franchise Tax Board & Income taxes & & \\
\hline & $\begin{array}{l}\text { California State Board of } \\
\text { Equalization }\end{array}$ & Sales and use tax registration & & \\
\hline & $\begin{array}{l}\text { California Department of } \\
\text { Alcoholic Beverage Control }\end{array}$ & Liquor license & & \\
\hline & $\begin{array}{l}\text { California Department of Fish } \\
\text { and Game }\end{array}$ & Fishing, hunting permits & & \\
\hline & $\begin{array}{l}\text { California State Department of } \\
\text { Industrial Relations }\end{array}$ & $\begin{array}{l}\text { California Occupational Safety and } \\
\text { Health Administration: Employee } \\
\text { safety plan }\end{array}$ & & \\
\hline & \multirow{2}{*}{$\begin{array}{l}\text { California Department of } \\
\text { Transportation }\end{array}$} & Entry onto state highway & & \\
\hline & & Signage license and fees & & \\
\hline \multirow[t]{2}{*}{ Federal } & Bureau of Land Management & Special-use permit & & \\
\hline & U.S. Forest Service & Special-use permit & & \\
\hline
\end{tabular}




\section{How Long Does It Take?}

How long it takes to obtain all of the necessary permits varies with the project and agencies involved. A simple project might receive its use permit within a month. Larger projects often take many months.

\section{Surviving Inspections: After the Use Permit Is Issued}

Anticipate regular inspections for health or environmental regulations. Get to know these inspectors. A positive relationship makes all the difference in how they perceive your operation.

\section{Permits, Licenses, and Your Business Plan}

\section{Estimate Permit and Licensing Fees}

When you finalize your business plan, it is important you include the costs of permits and licenses. Most counties have fees associated with the permit application process. Licenses, too, often require yearly renewal fees.

Frequently, there is a fee that accompanies your permit application and another fee required for your public hearing. Fees usually change annually, often after July 1 (the beginning of the fiscal year for most counties).

Figure 1 can help you estimate the fees and expenses involved in obtaining permits for your business. Complete it, filling in your start-up and

Regulations are part of doing business, and your compliance with them helps protect the operators and consumers from potential liabilities as well as protect the environment. annual cost. How will this affect your cash flow?

\section{Estimate the Costs of Compliance}

You are responsible for all costs. When you modify your facilities to meet use permit conditions or you construct a new barn in compliance with building codes, you pay the costs. Therefore, it makes sense to identify regulatory requirements early on so you can anticipate expenses and build them into your business plan.

\section{Resources}

\section{CalGold: California Government: On-Line to Desktops Business Permits Made Simple}

This website provides California business owners with information on permits, licenses, and other requirements of all levels of government agencies. http://www.calgold.ca.gov

\section{The California Planners' Book of lists}

This web site contains contact information for California city and county planning agencies and is updated annually.

http://www.calpin.ca.gov/archives/default.asp

\section{References}

George, Holly, and Ellie Rilla. 2008. Agritourism enterprises on your farm or ranch: Understanding regulations. Oakland: University of California, Division of Agriculture and Natural Resources, Publication 8333.

Keith, D., E. Rilla, H. George, R. Lobo, L. Tourte, and R. Ingram. 2003. Obstacles in the agritourism regulatory process: Perspectives of operators and officials in ten California counties. UC Agricultural Issues Center. 22:1-6.

Rilla, E., and H. George, eds. 2005. Agritourism and nature tourism in California. Oakland: University of California Division of Agriculture and Natural Resources, Publication 3484. 


\section{FOR FURTHER INFORMATION}

To order or obtain ANR publications and other products, visit the ANR Communication Services online catalog at http://anrcatalog.ucdavis.edu or phone 1-800-994-8849. You can also place orders by mail or FAX, or request a printed catalog of our products from

University of California

Agriculture and Natural Resources

Communication Services

6701 San Pablo Avenue, 2nd Floor

Oakland, California 94608-1239

Telephone 1-800-994-8849

(510) 642-2431

FAX (510) 643-5470

E-mail: danrcs@ucdavis.edu

\section{Publication 8334}

ISBN-13: 978-1-60107-581-9

(C)2008 The Regents of the University of California Division of Agriculture and Natural Resources

All rights reserved.

No part of this publication may be reproduced, stored in a retrieval system, or transmitted, in any form or by any means, electronic, mechanical, photocopying, recording, or otherwise, without the written permission of the publisher and the authors.

The University of California prohibits discrimination or harassment of any person on the basis of race, color, national origin, religion, sex, gender identity, pregnancy (including childbirth, and medical conditions related to pregnancy or childbirth), physical or mental disability, medical condition (cancer-related or genetic characteristics), ancestry, marital status, age, sexual orientation, citizenship, or status as a covered veteran (covered veterans are special disabled veterans, recently separated veterans, Vietnam era veterans, or any other veterans who served on active duty during a war or in a campaign or expedition for which a campaign badge has been authorized) in any of its programs or activities. University policy is intended to be consistent with the provisions of applicable State and Federal laws.

Inquiries regarding the University's nondiscrimination policies may be directed to the Affirmative Action/Staff Personnel Services Director, University of California, Agriculture and Natural Resources, 1111 Franklin Street, $6^{\text {th }}$ Floor, Oakland, CA 94607-5201, (510) 987-0096. For information about ordering this publication, telephone 1-800-994-8849.

To simplify information, trade names of products have been used. No endorsement of named or illustrated products is intended, nor is criticism implied of similar products that are not mentioned or illustrated.

\section{UC}

REVIEWED This publication has been anonymously peer reviewed for technical accuracy by University of California scientists and other qualified professionals. This review process was managed by the ANR Associate Editor for Farm Management and Economics.

pr-11/08-AS/CR 